\title{
AZ ENGLER-VISZKOZIMÉTER MODERNIZÁLÁSA
}

\section{MODERNIZATION OF THE ENGLER-VISCOMETER}

\begin{tabular}{|c|c|c|c|c|}
\hline \multicolumn{5}{|c|}{ Csomor Levente $^{1}$, Kakucs András ${ }^{2}$} \\
\hline $\begin{array}{r}{ }^{I} \text { Sapientia Egyetem, } \\
\text { l.csomor@yahoo.com }\end{array}$ & Marosvásárhelyi & Kar, & Mechatronika & $I V$ \\
\hline $\begin{array}{l}{ }^{2} \text { Sapientia Egyetem, } \\
\text { kakucs2@yahoo.com }\end{array}$ & Marosvásárhelyi & Kar, & Gépészmérnöki & Tanszék, \\
\hline
\end{tabular}

\section{Abstract}

Using the Engler-viscometer the viscosity is measured by performing a "time-of-discharge" test on a sample. The apparatus and the principle of the method is rather simple but the results can be affected by errors: we have proposed a method to reduce these errors.

Keywords: Engler-viscometer

\section{Összefoglalás}

Az Engler-viszkoziméter a kifolyási idők összehasonlítása alapján állapítja meg egy folyadék viszkozitását. A készülék eléggé egyszerü és a mérési elv is az, azonban néhány hibalehetőséget is felvet: mi ezekre kerestünk egy lehetséges megoldást.

Kulcsszavak: Engler-viszkoziméter

\section{Az Engler-viszkoziméter}

$\mathrm{Az}$ Engler-viszkoziméter a kapillárisviszkoziméterek kategóriájába tartozik. Egy rögzített geometriájú, termosztatikus tartállyal rendelkezik, amelyet egy adott szintig kell feltölteni a mérendő folyadékkal. Ez a tartály alján egy standardizált csövecskén keresztül tud kifolyni.

A mérés $2 \mathrm{dl}\left(200 \mathrm{~cm}^{3}\right)$ folyadék kifolyási idejének mérése alapján történik [2], jelöljük ezt $t_{x}$-szel. A készülék ,állandója” a $2 \mathrm{dl}, 20{ }^{\circ} \mathrm{C}$ hőmérsékletü desztillált víz kifolyási ideje, jelöljük azt $t_{\mathrm{o}}$-val (ez tipikusan $51 \pm 1 \mathrm{~s}$ szokott lenni). A viszkozitás mértéke (de nem az abszolút értéke) a $t_{x} / t_{o}$ hányados, amely egy dimenzió nélküli menynyiség ugyan, de ,Engler-fok” ( $\left.{ }^{\circ} \mathrm{E}\right)$ megnevezéssel vonult be a müszaki köztudatba.
Az ilyen módon megadott viszkozitásból az áramlástanban használt kinematikai viszkozitást összehasonlítások alapján lehet meghatározni; erre a szakirodalomban különféle táblázatokat, nomogrammokat lehet találni, de létezik egy átszámítási formula is:

$$
n=\left(7.32 \times{ }^{\circ} \mathrm{E}-\frac{6.31}{{ }^{\circ} \mathrm{E}}\right) \times 10^{-6}\left[\mathrm{~m}^{2} / \mathrm{s}\right]
$$

(a képlet zárójele centistokes-ban adja a kinematikai viszkozitást).

Ha a mérés menetéről magyarul szeretnénk olvasni, akkor azt tapasztalhatjuk, hogy eléggé nagy káosz uralkodik a szakirodalomban: több helyen az fordul elö, hogy a kifolyási időket azonos körülmények között kell összehasonlítani, például, ha $50{ }^{\circ} \mathrm{C}$ hőmérsékletű olaj viszkozitását akarjuk megállapítani, akkor a desztillált 
víz kifolyási idejét is ugyanezen a hőmérsékleten kell elvégezni. Egy jó kérdés az, hogy miként járjunk el a $150{ }^{\circ} \mathrm{C}$ hőmérsékletü olajjal, avagy hogyan határozzuk meg pl. az $50{ }^{\circ} \mathrm{C}$ hömérsékletü desztillált víz viszkozitását?

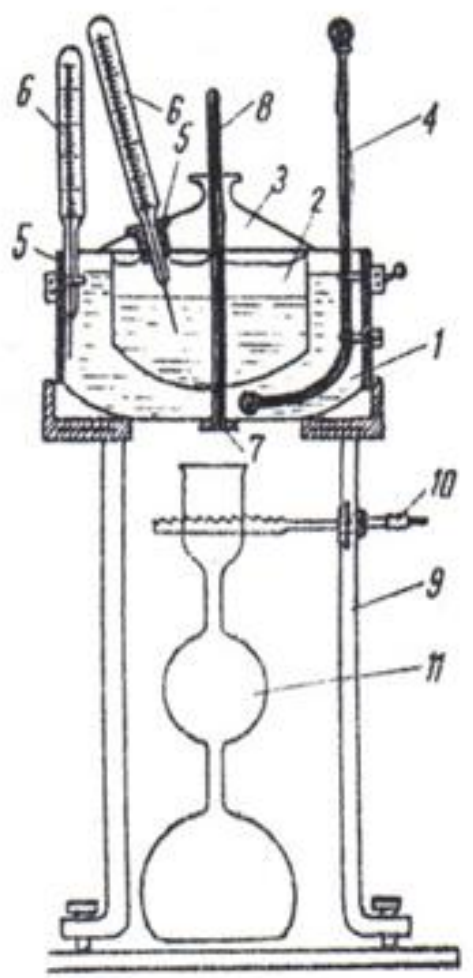

1. ábra. Az Engler-viszkoziméter

A mérendő térfogat körül is van némi zürzavar, ugyanis ellenőrzésképpen két időt is regisztrálni lehet: $1 \mathrm{dl}$, illetve 2 dl kifolyási idejét (a viszkoziméter edényén rendszerint mindkét térfogathoz tartozó szint meg van jelölve), de a tulajdonképpeni Engler-fokban megadott viszkozitást $2 \mathrm{dl}$ folyadék kifolyási ideje alapján kell megállapítani.

$\mathrm{Az}$ Engler-viszkoziméter mérési elve nem sokban különbözik az Ostwaldviszkoziméterétől, amely szintén egy kapil- láris viszkoziméter, de az egy inkább laboratóriumban használt üveg-készülék. Lehet, hogy az elöbbi pontatlanabb, viszont több fajta folyadék esetében használható (festékek, kőolaj-származékok, egyéb átlátszatlan vagy nehezen kimosható folyadékok).

$\mathrm{Az}$ Engler-viszkoziméter nem egyeduralkodó a saját kategóriájában sem: hasonló felépítéssel és mérési elvvel rendelkezik az Egyesült Királyságban használt Redwood-viszkoziméter, valamint az Egyesült Államokban használt Saybolt-viszkoziméter.

\section{A mérési hibák lehetséges forrá- sai}

A kifolyási idő mérésének a kezdete a viszkoziméter kapillárisát elzáró tü felemelésének a pillanata, a vége pedig az a pillanat, amikor a folyadékszint eléri a gyüjtöedény falába karcolt, 2 dl-nek megfelelő jelet. A manuális gépek esetében ez azt jelenti, hogy a méréseket elvégző személy az egyik kezével felemeli a tüt, miközben a másikkal elindítja a stopperórát, majd a folyadékszintet figyelve, amikor úgy véli, hogy az elérte a jelet, megállítja azt. Ebbe a folyamatba kétszeresen is beépül az emberi reakcióidő, ugyanakkor a folyadékszint szemmel történő megállapítása leolvasási hibákhoz vezet: egyrészt szemmel még a nyugvó folyadékok szintjét is $\mathrm{kb}$. fél milliméter pontossággal tudnánk megállapítani, ami egy $10 \mathrm{~mm}$ átmérőjű nyakban a térfogat meghatározásában $\pm 0.04 \mathrm{~cm}^{3}$-es hibát jelent. Ez a $200 \mathrm{~cm}^{3}$-hez viszonyítva ugyan nem sok, a problémát inkább a csordogáló folyadék által keltett buborékok és az üvegedény falára tapadó cseppek jelentik, amelyek miatt a térfogatot csak ennél nagyobb hibával tudjuk leolvasni.

A térfogat meghatározásában a másik hibalehetőség a hőtáguláshoz köthető: a mérés elve szerint 2 dl folyadék kifolyási idejét kellene megmérni, csakhogy a forró folyadékoknak a mérés ideje alatt van ide- 
jük kihülni, mivel a mérőedény nem termosztatikus. A folyadékok hőtágulási tényezője $10^{-4} \mathrm{~K}^{-1}$ nagyságrendü, ami $100{ }^{\circ} \mathrm{C}$ hőmérséklet-különbség mellett $1 \%$ nagyságrendü hibát okoz, ami jóval nagyobb az előbb említett leolvasási hibánál. Erre a hibalehetőségre utal egy régebbi tanulmány is [1], amely nem az Engler-, hanem a Redwood-viszkoziméter standardizálásáról szól.

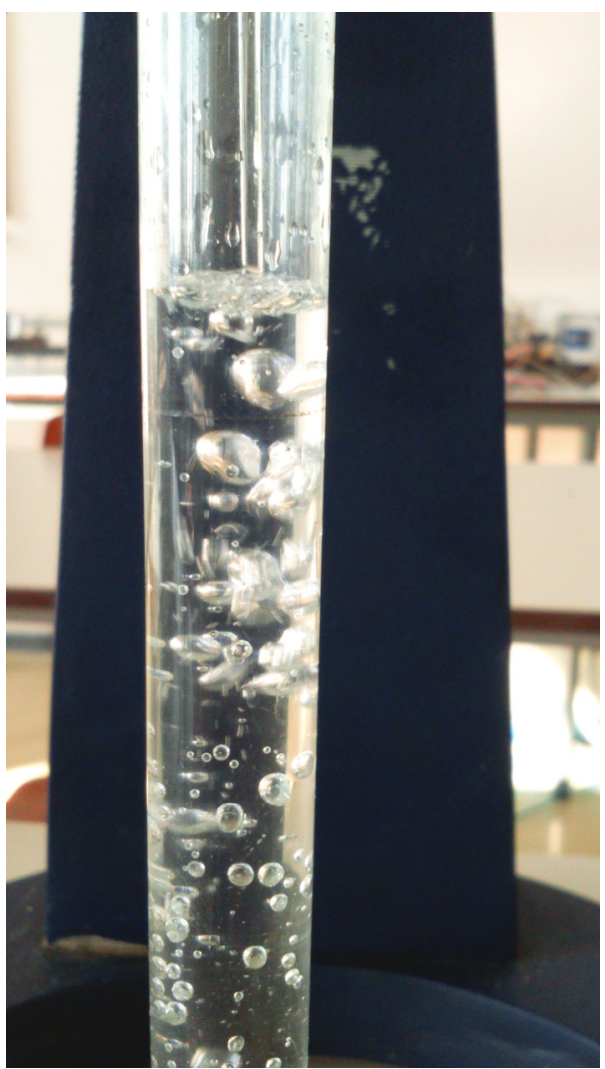

2. ábra. A folyadékszint megállapitásának nehézségei

\section{A mérési folyamat automatizá- lásának lehetőségei}

A manapság kapható laboratóriumi Engler-viszkoziméterek részben automati- záltak: ez azt jelenti, hogy a hőmérsékletnek a beállított értéken tartását egy szabályzó-rendszer végzi (rendszerint csak füt, de a hütés is megoldható lenne), a kronométer pedig a tü felemelésével automatikusan indul, a kijelzője pedig nem (vagy nemcsak) az időt mutatja, hanem az Englerfokban megadott viszkozitást.

Úgy tünik, hogy a folyadékszint automatikus leolvasása viszont már egy nehezebben megoldható feladat.

Számba vettük a lehetséges egyszerü megoldásokat: a folyadékszint úszókával való detektálása a buborékos-hullámzó felület miatt nem lenne pontosabb a szemmel való leolvasásnál, ráadásul a folyadék fajsúlyától is függ az, hogy mikor emelkedik meg az úszóka, a megvalósítás is elég bonyodalmas lenne a mérőedény szük nyaka miatt.

Egy másik lehetőség lett volna a folyadékszint optikai módszerekkel történő detektálása, azonban az üveg falán megtapadó cseppek miatt ez is bizonytalanul müködne.

Jobb ötletnek tünik a hőmérséklettől is befolyásolt térfogat helyett tömeget mérni: egy kellöképpen pontos mérleggel (érzékelővel) kiküszöbölhetők a folyadékszint vizuális megállapításához köthető hibalehetöségek, ugyanis a sürüség ismeretében ki lehet számítani azt, hogy mekkora a tömege van a 2 dl mérendő folyadéknak. E módszernek a további előnye az lenne, hogy a mérleget be lehet építeni a viszkoziméter vezérlő-áramkörébe: a kronométer megállításának a pillanata az lenne, amikor a mérleg a 2 dl folyadék tömegét jelzi (ezzel kiküszöbölhető az emberi reakcióidő hatása is).

A módszernek azonban nemcsak elönye, hanem hátránya is van: meg kell állapítani a mérendő folyadék sürüségét is. Az eredeti eljárás szerint a térfogatmérés a gyüjtöedényben történik, tehát valahol a környezet és a termosztatikus tartály hömérséklete közötti, bizonytalan ponton (mivel a folyadék közben hül, vagy melegszik). Mivel a 
kifolyási idő a tartályban levő folyadékszinttől (a tartály alján, a kapilláris bemeneténél mérhető hidrosztatikai nyomástól) függ, kézenfekvőnek tünik az a javaslat, hogy a sürüség a tartály hőmérsékletén legyen meghatározva és nem pl. a szobahőmérsékleten.

\section{A megvalósítás, következtetések}

Adott egy hajdanában félig automatizált Engler-viszkoziméter, amelynek az elektronikája elromlott. Ehhez fogunk egy új rendszert építeni, amelynek a középpontja egy Raspberry Pi 3 mikroszámítógép [3]. Ehhez a GPIO csatlakozón keresztül közvetlenül illeszthetünk érzékelőket és reléket, így nincsen szükség egy adatgyüjtőre is.

Ilyenképpen a viszkoziméter tartályának a hőmérsékletét egy beépített érzékelővel követhetjük, a $220 \mathrm{~V}$-os fütőellenállást pedig egy relén keresztül kapcsolgatjuk a beállított hőmérséklet tartásához.

A mérés kezdetekor, a tü felemelésének a pillanatát egy mikrokapcsoló jelzi (ez még a régi rendszer tartozéka volt).
A kifolyt folyadék tömegét egy erömérő cella (ez tulajdonképpen egy hajlított rúd, nyúlásmérő bélyegekkel) méri: amikor az eléri a beállított, 2 dl folyadéknak megfelelő értéket, akkor az időmérés megáll.

A Raspberry PI 3-hoz billentyüzetet, egeret és egy számítógép-képernyőt is csatlakoztathatnánk, de mindezt kiváltjuk egy közvetlenül hozzá építhető érintőképernyővel: így a felhasználó egy kompakt rendszeren dolgozhat, amin beállíthatja a kívánt paramétereket (hőmérséklet, tömeg) és követheti a mérési folyamatot.

\section{Szakirodalmi hivatkozások}

[1] Winslow H. Herschel: The Redwood viscometer. Technologic Papers of the Bureau of Standards, 1921, http://nvlpubs.nist.gov/nistpubs/nbstechnolog ic/nbstechnologicpaperT210.pdf

[2] Dabir S. Viswanath, Tushar Ghosh, Dasika H.L. Prasad et al.: Viscosity of Liquids: Theory, Estimation, Experiment, and Data. Springer 2007

[3] https://www.raspberrypi.org/products/raspbe rry-pi-3-model-b/ 